\title{
"Let id prevail over ego!": The Specter of Gay Nihilism in American Drama Criticism of the 1960s
}

\section{Doug Arrell}

In August 1963, Joseph Hayes, a commercially successful playwright whose best known work is The Desperate Hours, published an article in The New York Times entitled "Distorted Views: Theatre Misrepresents Life in America." In it he attacked some contemporary playwrights, specifically Tennessee Williams and Edward Albee, for their nihilism. The tone is apocalyptic; we are living at a time when "the everpresent negative forces of a perilously balanced universe can finally win in a total way"; the theatre is liable to push us off the edge, presenting as it does "a picture of man's hopelessness, lack of significance or value under an empty scowling sky, his self-deluded stupidity, cupidity, contemptible puniness - his utter worthlessness." This view derives, not from the playwrights' genuine despair for humanity, but from "their own self-orientated sickness. This pity is all for self; this vision is personal and private." He suggests that the playwrights producing these "images of neuroticism and nihilism" are actually "mocking us," and that American civilization will pay dearly for it by "the slow corrosion of the only beliefs that might give meaning to an existence that these writers contend is meaningless." He expresses the fear that "those private visions of hell with which we are being assaulted will become no longer private and individual but general and universal. The defeat will then be total, final."

Though he never mentions homosexuality, no reader in 1963 could miss the fact that this is what Hayes is talking about, that he is joining in the outcry against homosexual influence in the theatre that first found overt expression in a 1961 article by Howard Taubman, the drama critic for The New York Times, and subsequently found support among most of Broadway's critics. ${ }^{2}$ In addition to many code words_-"distorted," "sick," "neuroticism," "viciously," "private"- Hayes makes his point more explicitly by evoking the theory that the characters in Who's Afraid of Virginia Woolf? are really homosexual men in disguise, a critical motif that had become a touchstone for those attacking homosexual influence in the theatre: "Does the waspish bitchiness of the dialogue in 'Virginia Woolf,' for instance, correspond to a recognizable pattern of the speech in a marriage or to some other relationship

\footnotetext{
Doug Arrell recently retired as Professor in the Department of Theatre and Film at the University of Winnipeg, where he was Chair for nine years. He did his undergraduate work at the University of Toronto and obtained his $\mathrm{PhD}$ at the University of London. He was a founder and first Secretary-Treasurer of the Canadian Lesbian and Gay Studies Association. He is a director and dramaturge and the author of articles on Canadian theatre history, queer studies, and aesthetic theory.
} 
out and beyond the experience of most of us." ${ }^{\prime 3}$ The outcry about homosexuality in the theatre was only part of a wider hysteria about homosexual influence on American culture in general during this period. The remarkable extent of this phenomenon, which reached its peak in the mid 1960s, is documented in Michael S. Sherry's recent book Gay Artists in Modern American Culture: An Imagined Conspiracy. ${ }^{4}$ In this essay I will explore a particular aspect of this anti-homosexual outburst, one well illustrated by Hayes's article. While many critics complained of the misogyny and dishonesty of gay male artists, among some there was a deeper concern that their work was profoundly anti-humanistic and posed an imminent danger to American civilization. These critics focused on nihilism as the greatest threat posed by the gay artist, and their writings often took on an apocalyptic tone. Oddly enough, it was often the more intellectual and liberal writers who took this position, as I will illustrate in the writings of several commentators of the period, notably the theatre critic Robert Brustein. I will suggest that understanding how this particularly extreme position evolved helps explain both the rapid rise of critical homophobia during this period and its equally rapid decline.

The association of nihilism with homosexual men has its source in Freud. He produced at least four theories of the etiology of homosexuality in the course of his career; although they vary significantly in detail, all revolve around a failure on the part of the male child who will be homosexual to develop a fully adult self. Specifically, one way or another he fails to pass through the oedipal phase. It is during this stage that the heterosexual male child copes with his guilt for his desire to kill his father, whom he views as a rival for his mother's love, by identifying with his father; he internalizes his father's disapproval by creating a super-ego, the conscience that forces the ego to conform to moral rules and societal laws. The implication of Freud's theory is that homosexual men, who never achieved this identification with their fathers, lack a super-ego. Freud himself never explicitly drew this conclusion, but it became the accepted view among most of his American followers that homosexual men had "defective" super-egos. In his history of the psychoanalytic view of homosexuality, Kenneth Lewes notes that by the 1960s this view had become "a cliché in certain psychoanalytic circles," and was held by two of the most respected (and now notorious) authorities on homosexuality, Irving Beiber and Charles Socarides. ${ }^{5}$ In effect these psychiatrists were saying that homosexuals were deficient in a sense of morality and social responsibility, were lacking in ideals or commitment to the values of civilization, and in this sense were nihilists. This extremely negative assessment of the human potential of gay men prevailed in a period when psychoanalytic theory and practice played a dominant role in American culture both in the popular media and among intellectuals.

Prominent among the leaders of American thought during the post-war period were the members of the New York intellectual circle surrounding the Partisan Review. In many ways, Freud had replaced Marx as the intellectual icon of this 
group, a surprising shift that can only be explained by the fact that both figures were selectively read as exemplifying basically liberal humanist values. In the case of Freud, this meant an emphasis on texts such as Civilization and Its Discontents (1930). This work was understood as portraying civilization as the product of the heroic efforts of the ego, egged on by the super-ego, to impose reason and justice on the powerful anarchic force of the id. In tune with the post-war mood, and reflecting disillusion with the optimism of Marxism, the victory of the ego was seen as a Pyrrhic and ultimately tragic one, in which human desires are sacrificed to achieve a stable social structure. Civilization and Its Discontents was probably the most widely read of Freud's works outside the psychoanalytic community; since it states explicitly that the super-ego, in spite of its sometimes oppressive effect on the ego, is the key to the survival of civilization, many intellectuals came to view the super-ego as the source of all the higher virtues of Enlightenment humanism including morality, reason, and self-control. ${ }^{6}$ Lionel Trilling, who was in many ways the leading figure in the New York group and its most committed Freudian, included this work as required reading for his students at Columbia. The tenor of his thinking can be seen in a 1961 article in the Partisan Review, in which he describes his disappointment with their response to it:

The pain that civilization inflicts is that of the instinctual renunciation that civilization demands, and it would seem that fewer and fewer people wish to say with Freud that the loss of instinctual gratification, emotional freedom, or love, is compensated for either by the security of civilized life or by the stern pleasures of the masculine moral character. ${ }^{7}$

Trilling posits that the masculinity of moral character derives from the fact that it is something that heterosexual boys inherit from their fathers; without it (and it appears to be under threat) the battle for civilization would be lost. Its clear corollary is that those who lack this character and give in to "instinctual gratification," notably male homosexuals, are a threat to civilization. This conclusion is implied, albeit obliquely, in comments Trilling made about the Kinsey Report. He rejects Kinsey's portrayal of homosexuality as a natural form of sexuality that should not be viewed judgmentally; he notes that most psychiatrists view homosexuality as the result of "some warp—as our culture judges it—of the psychic structure" and that "the condition that produced homosexuality also produced other character traits on which judgment could be passed." He adds that "there can be no doubt that a society in which homosexuality was dominant or even accepted would be different in nature and quality from one in which it was censured." refers to are obviously the symptoms of a defective super-ego as described by psychiatrists like Bieber and Socarides, and the potential effects on society so 
discreetly alluded to are the decivilizing ones feared by most of the commentators discussed in this essay. Trilling's views were widely influential on all who aspired to join the select group of New York intellectuals, including the more literate and intelligent among drama critics.

In essence, the prevailing view among psychiatrists was that homosexuals were adult infants, who never got beyond the worldview of babyhood. A good example of this thinking is to be found in a 1965 article in the Tulane Drama Review, "Homosexuality and the American Theatre: A Psychoanalytic Comment," by Donald M. Kaplan, a New York psychiatrist who clearly numbered many theatre people among his clients. He views homosexuality as a hold-over from the "polymorphous perverse" phase of infantile sexuality; the homosexual child lacks the sense of guilt that causes the heterosexual child to turn away from his "infantile sexual ambitions" and the sense of limitation that normal males develop to curb their nongenital sexual urges. ${ }^{9}$ The adult homosexual is a rebel against societal conventions:

But he is a rebel of a particular sort. "The freedom he demands," as Camus said of Sade, "is not one of principles, but of instincts." Thus, as an ideologist, when he sides with the victim against the oppression of God or society, the homosexual's ideologic style does not champion humanity, but merely himself. Ideology, whose sole program is instinct, that is, behaviour without responsibility - a program ultimately without action - is merely nostalgic for justice and reformation, but is actually seeking restoration of the spoilt child, a bit of which is lively in every victim, as well as oppressor. Intelligence, discrimination, and reason - the dawnings of the post-Oedipal child and the neutralizers of defiling domination-have little status in a homosexual ideologic style..$^{10}$

In denying homosexuals "intelligence, discrimination, and reason" Kaplan is clearly alluding to their defective super-egos, which have left them with an infantile view of the world. Homosexuality is similarly equated with immaturity in a notorious 1966 article, "The Homosexual in America," in Time; the anonymous author suggests that both male and female homosexuals "are essentially a case of arrested development, a failure of learning, a refusal to accept the full responsibilities of life." ${ }^{11}$ References to homosexuals as victims of "arrested development," as immature or childish, are frequent in the writings of this period. In his reviews in Commonweal Wilfrid Sheed twice refers to aspects of plays by homosexual playwrights as being from the "nursery." 12 All this implies that homosexual men remain spoilt children, that they lack the basic adult human characteristics of a moral conscience and self control.

Another notorious implication of Freud's theory is that women, who also do 
not pass through the oedipal phase, also lack a super-ego. Eventually Freud was able to develop a theory that gave women something of the same maturation he attributed to men, but in fact Freud always believed that women did not have a fully developed super-ego, and so were less moral and reasonable than men. ${ }^{13}$ Thus Freudian theory reinforced gender roles, especially in the post-war era when psychoanalysts were at the height of their popular influence. The qualities that heterosexual men supposedly developed through identification with their fathers in resolving the oedipal crisis - the ability to curb their sexual appetites, to conform to the requirements of society, to provide for and dominate their families and advance in their careers - were key components of the ideal of masculinity to which most men in post-war America aspired. Failure to conform to any aspect of this ideal - by failing to marry, or to support a family, or to live up to one's responsibilities were in fact viewed by many psychiatrists as symptoms of latent homosexuality. In effect, as Barbara Ehrenreich points out, the conventional male role as monogamous breadwinner was policed by the threat that any deviations from it were symptoms of one's being, or likely to become, this most despised male type. ${ }^{14}$

Ehrenreich's book The Hearts of Men focuses on a number of deviant images of masculinity that arose in the 1950s that became a topic of intense media interest, notably the playboy bachelor, the beatnik, and the teenage rebel. Of course, all three images were stigmatized as homosexual. The swinging bachelor suffered from the Don Juan complex and was in fact latently homosexual; the beatnik, as exemplified by Allen Ginsberg and William Burroughs, actually was homosexual or on his way to becoming so; the teen rebel was latently homosexual and had been popularized by homosexual artists and the homosexually-dominated media. To the "organization men" of the 1950s caught up in the rat race and the long commute to the suburbs, these images — of sexual freedom, avoidance of responsibility, and non-conformism - were secretly appealing, but also highly threatening, since they undermined the image of masculinity to which they had devoted so much effort to conform. Here, I think, is the key to the apocalyptic tone of some of the writing on the influence of homosexuality on American culture of the period: to give in to these homosexually tainted images would mean to abandon the male identity around which most men had built their lives.

Because two of the most important playwrights of the 1950s, Tennessee Williams and William Inge, were widely known to be homosexual, theatre became an important locus for the development of the theory that artists with defective super-egos were undermining American masculinity. For many critics the first sign of this influence came when Marlon Brando as Stanley Kowalski removed his t-shirt under the gaze of Blanche Dubois in A Streetcar Named Desire in 1948. One does not need to accept all the neo-Freudian super-subtleties in Laura Mulvey's oft-cited article "Visual Pleasure and Narrative Cinema" to recognize the validity of her most famous thesis: that in a patriarchal society, such as America in the 1950s, men are 
subjects of the gaze and women are its objects. In other words, men gaze at women with sexual interest, but men, as Mulvey says, "cannot bear the burden of sexual objectification." "15 The threat of the sexualized male body to conventional images of masculinity was underlined when Hal in Inge's Picnic (1953) also removed his t-shirt and his muscular body was clearly the object of the gaze of all the female members of the community. In his review of this play, Eric Bentley hints that this sexualized portrayal of men is a kind of militant stance on the part of homosexual playwrights: "The torn shirt of Stanley Kowalski ... is a symbol, a banner, an oriflamme. It stands for the new priapism.” Bentley, who was himself homosexual but like many others of his time undergoing psychoanalysis, introduces a theme that will reappear in later criticism: homosexual playwrights are corrupting society by substituting sex for higher (i.e., super-ego related) topics, such as morality or social betterment. ${ }^{16}$ Like many later critics, Bentley sees the glorification of the male body as a denial of more important aspects of masculinity:

There is of course no denying that a hero has a body and that it is a male body. What is remarkable in certain plays of Williams and Inge is that so much is made of the hero's body and that he has so little else. The rose that, for Eliot, is rooted in so deeply and broadly human a garden blooms, for Williams, on the bared chest of pseudo-primitive man. ${ }^{17}$

Like later critics also, Bentley suggests that there is something false or "pseudo" about the masculinity portrayed by homosexual playwrights.

Both Streetcar and Picnic were made into highly successful films, and the image of the newly sexualized male body was promulgated far and wide. By the mid-1950s, it was associated by many commentators with other disturbing cultural developments, notably the rise to media prominence of the juvenile delinquent and the beatnik or hipster. Brando went on to play other variations on the sexually charismatic working-class male; he was joined by James Dean as another masculine sex object. Their roles in The Wild One (1953) and Rebel Without a Cause (1955) established the image of the teenage rebel that further upset the conventional canons of masculinity. At the same time, the rise of the hipster and the beat poets was widely viewed as the intellectual equivalent of the delinquency phenomenon. How all this came together can be seen in an article contributed by novelist Herbert Gold to a special feature on "The Beat Mystique" that appeared in Playboy in 1958. Gold clearly connects the beatnik with the teenage rebel: "the movie shadow of Dean or the Brando of The Wild One is part of the image of the hipster." The connections seem to be narcissism, amorality, and emotional disconnection, as the following passage implies: "In many theatres, where The Wild One played, there was a lineup afterwards in the men's room, the cyclists in their nail-studded black jackets 
scowling with adoration in the mirror as they rehearsed their public roles. Each man was Brando, distant and violent. Each man was Marlon, cool and beat." Gold refers to the fact that Freud "valued society despite the discontents of civilization" while the hipster "gives up society, gives up intelligence"; the implication is that the hipster lacks the super-ego that Freud said makes civilization possible. ${ }^{18}$ There are also hints at the connection with homosexuality:

The coolest boys call each other "daddy-o," as if their passivity extends to thinking of every man as a potential guardian father . . .. They worship the purple fantasy of torn-tee-shirted masculinity created by Tennessee Williams, William Inge, and others who have invented a new theatrical type - the male impersonator. Adorably brutal, stripped of the prime attributes of manlinessintelligence, purpose, control--they are the curvaceous Mae Wests of popular melodrama. ${ }^{19}$

We sense strongly here Gold's disgust at the portrayal of the male body as the object of the sexual gaze, and his concern to blame it on homosexual playwrights. He wants to defend the patriarchal definition of manhood - embodied in the superego's virtues of intelligence, purpose and control - and his coining of the term "male impersonator" nicely captures his sense both of the falsity of the image of masculinity projected and its homosexual origins. ${ }^{20}$ The article in which this passage is embedded is a clear expression of the paranoid response of many men to the challenging new images of manhood appearing in the media in the late 1950s, and their apparent growing popularity and influence.

A similar response in a more muted form is reflected in two articles by the very young Robert Brustein, who was to become one of America's most distinguished drama critics. The first of these, "America's New Culture Hero," which appeared in Commentary in 1958, was an analysis of the teenage rebel figure, who is associated as Brustein says with "sex, violence and incoherency." Like most commentators, Brustein sees the immediate origins of this figure in Williams's and Brando's Stanley Kowalski. In an analysis of the films of Brando and especially of James Dean, Brustein sees a Freudian pattern of a "disguised family romance"; the boy's rebellion against society is merely an extension of hostility to his father, and the hero's inarticulacy is a rejection of "the teachings of the father, the complexity of the world, the discipline of a developing intelligence, the gifts of tradition, history, science and art." In other words, the new culture hero is one who has failed to navigate the oedipal phase, which means that he has failed to develop a rational and moral super-ego, and hence is doomed to perpetual immaturity. Brustein could count on his readers to fill in the subtext: the new culture hero was also latently homosexual. Very subtly, Brustein hints that the glorification of male immaturity in 
contemporary culture is the work of homosexual artists when he says that "we can see how much of the acting and writing of the inarticulate hero is not only neurotic but conformist." 21 The term "neurotic" here is a code word for homosexual that appeared frequently in the writings of the period.

In the same year, Brustein wrote an article entitled "The Men-taming Women of William Inge" for Harper's. His thesis is that in Inge's plays we find "a view of man as blandly nerveless as that held by Rodgers and Hammerstein--and more sinister since it robs the individual of his aspiration, his heroism, and even his manhood." Inge's plays present "the situation of the helpless childman and the comforting mother-woman in progressively disguised form." ${ }^{22}$ Citing a reference in Picnic to the fact that the women of the town had the penis removed from the statue of a gladiator in the library, he claims that "most of Inge's heroes have the physical and cultural characteristics of this gladiator, and all of them have a hidden fear of sharing through their contact with women, his emasculation." He then cites Gold's term "male impersonator" to refer to the Inge hero, and paraphrases Gold's argument:
A direct descendant of Stanley Kowalski in Streetcar Named Desire, he dresses in a conventional uniform consisting of blue jeans, cowboy boots, and tee-shirt (which the hero invariably has an opportunity to remove), and is equipped with bulging biceps and enormous sexual potency. He proclaims his manhood in much the same way that Jayne Mansfield proclaims her womanhood, not by evidence of maturity, intelligence or control but by exaggerated physical characteristics. ${ }^{23}$

While acknowledging that in real life "the man who hides fundamental insecurities behind an exaggerated show of maleness" is very likely to end up "in a filial, dependent relationship with his wife," Brustein feels that "what is suspect is the ambiguity and the persistence with which Inge presents the same situation." He ends by suggesting that Inge views the world as a child does: "it is, after all, a child's world where social and moral issues assume no importance and where whatever is dark and evil can be expunged by the comfort of a woman." ${ }^{24}$ In all of this the student of Freudian theory can recognize Brustein's implied reference to Inge's sexuality. In perhaps his best known theory of homosexuality, Freud portrays the male child who will be homosexual as both excessively attached to his mother and experiencing an excessively strong castration anxiety that causes him to recoil in horror from her and all women when he discovers she lacks a penis. ${ }^{25}$ This ambivalent attitude is what Brustein means when he refers to the "ambiguity" in Inge's portrayal of the female-male relationship, which is both motherly and castrating. Brustein stresses the consequences of Inge's lack of a super-ego, which 
means not only that his masculine ideal lacks "maturity, intelligence or control" but that for him "social and moral issues assume no importance." In his use of terms like "sinister" and "suspect" Brustein hints at the evil social effects of the homosexual presence in the theatre; this marks one of the first signs of a much more aggressive attack on the homosexual playwright that will occur among New York critics in the early 1960s.

The playwright who for many critics epitomized the amoral homosexual was Jean Genet. Most saw his work through the intensely homophobic prism of Jean-Paul Sartre's depiction of him in his book Saint Genet. For Sartre, Genet's homosexuality resulted from the fact that, at the age of ten, he was accused of being a thief, and consequently he abandoned his status as Subject and became the Other, which among many other things meant becoming a "passive" homosexual. This mirrors somewhat the Freudian theory of the homosexual's failure to achieve identification with his father and so to develop a normal adult self. ${ }^{26}$ Critics often praised Genet for his honesty, as against the dishonesty of American homosexual playwrights. As John Clum points out, on the face of it this seems strange, since Genet's well-known plays do not present homosexuality any more directly than do those of Williams or Albee. ${ }^{27}$ I suspect the critics were referring to Genet's honesty in expressing his nihilism, his rejection of all civilized values, which they felt was the "true" homosexual's attitude, normally disguised by playwrights pretending to moral seriousness. Robert Brustein, writing in 1960, presented the conventional liberal view of Genet's works when he stated that he is "the most gifted, and the most depraved of the new French dramatists" whose "violent demolition of established authority" is "both appealing and appalling": "If you consider yourself a good citizen concerned with preserving the social contract, you might feel inclined to stone the author and picket the [theatre]; but if you are curious to know what the theatre can be like when a perversely honest immoralist writes for it [go and see The Balcony]. ${ }^{28}$ Herbert Blau, in his 1964 book The Impossible Theatre, is more explicit about the Freudian connection between Genet's homosexuality and his nihilism. Blau was known for his productions of Genet's plays at the San Francisco Actor's Workshop, but his fascination with the French playwright was mingled with apprehension. He states that "Genet's allegories ... have taken us way beyond the drama of inept sympathies back to a pregenital, pre-oedipal world of the primal Mother, culminating in the castration rites of The Balcony, as well as the exaltation of shit (the environment of the cradle) in The Screens." Blau stresses Genet's superiority to current American homosexual playwrights, noting "this is not the erogenous zone of prepubic sexuality which has broken out on Broadway"; but in spite of his admiration for Genet, Blau's discussion of him reflects his awareness of the dangers he presents: "There is a cleansing of the ego; dark energies are released." Though this may serve a useful purpose in America's complacent, bourgeois theatre, his negativity in the long run could be harmful; Genet's supposed complete lack of 
humanity and morality leads Blau to cite sympathetically a statement he attributes to W. B. Yeats: "I say against all the faggots that it is our first business to paint, or describe, desireable people, places, states of mind." ${ }^{29}$

Unlike most of the other critics discussed here, Blau did not repudiate or even veil his anti-homosexual attitudes after the 1960s. His 1982 essay "Disseminating Sodom" is one of the few examples of the open expression of these attitudes by a liberal writer of this era; although it was published well beyond the period discussed in this essay, it provides valuable background to The Impossible Theatre (which contains many signs of a similar view of homosexuality) and interesting parallels to the thinking of other critics of the 1960s. Couched in the fashionable jargon of post-structuralist thought combined with Blau's own brand of quasi-poetic prose, the tone of this essay is definitely apocalyptic; civilization is apparently on the verge of reverting to a pre-oedipal phase of sexual behavior, one in which there are no taboos, no distinctions of gender, and indeed no distinction between self and other. Among the signs Blau mentions of this impending catastrophe are the Profumo affair, Chappaquidick, the exposure of Wilbur Mills, "fucking on the steps of the Lincoln Memorial," the new German film, Violent painting, and punk music. The dangers from militant homosexuals and what he calls the "new homosexual discourse" is that, because homosexuals are unhappy with their lives and unable to achieve acceptance from heterosexuals, they are seeking to win society as a whole over to their pre-oedipal sexuality. The new homosexual discourse aims, he says, at

altering our conceptions of sexual possibility, causing us to rethink the nature of masculinity and femininity (or our resistance to the rethinking), every lymph node and sensuous capillary of the labyrinth of gender, raising the alluring threatening prospect of a polysexuality irrespective of gender (sometimes of persons) and other classifications as well, age, criminality, neurosis, cruelty, madness, family (nest of incest), biological species. ${ }^{30}$

The actual discourse Blau refers to is mainly the work of French post-structural feminists like Cixous and Irigaray; the sexuality they seek to liberate is above all that of women, although, like virtually all of the writers I am discussing, Blau refers entirely to male homosexuality. The overall tone of the essay is one of fear-fear of opening the floodgates of unconventional sex, of anarchy and gender confusion, above all loss of identity. When he is confronted with "the homosexual discourse and its corrosive deconstructions of what I may represent," he is forced to take action against it; in doing so he is "refusing the slippage of ego, however constrained by heterosexual categories, however illusory it might be." ${ }^{31}$ Given that the discourse he fears is primarily feminist discourse, one feels that at the heart of 
Blau's anxiety is the fear of losing his traditional heterosexual male self-image. Although Blau is unusual in maintaining this attitude into the 1980s, I will argue shortly that this fear (or a version of it) was at the heart of the apocalyptic antihomosexual writing of the 1960s.

A common criticism of the work of homosexual artists was that it was all style and no substance. According to Stanley Kauffmann:

[Homosexual artists] exalt style, manner, surface. They decry artistic concern with the traditional matters of theme and subject because they are prevented from using fully the themes of their own experience.... Thus we get plays in which manner is the paramount consideration, in which the surface and the being of the work are to be taken as its whole. Its allegorical relevance (if any) is not to be anatomized, its visceral emotions (if any) need not be validated, and any judgment other than a stylistic one is considered inappropriate, even censorious.... Not all artists and critics who advance this theory of style-as-king are homosexuals, but the camp has a strong homosexual coloration.... By adulation of sheer style, this group tends to deride the whole culture and the society that produced it, tends to reduce art to a clever game which even that society cannot keep them from playing. ${ }^{32}$

The full significance of this widely-held view of the art created by homosexuals can only be understood if one recognizes that homosexuals were viewed as pathologically deficient in the moral sense, and unable to appreciate "traditional matters of theme and subject." Although Kauffmann attributes their indifference to moral and social issues to their inability to describe their own homosexual experience in a world that rejects them, his interpretation of their work in fact evokes this highly prejudicial view, one that denies homosexuals true humanity. This is on a par with the rest of Kauffmann's essay, which while ostensibly sympathetic is subtly homophobic throughout, as I have argued elsewhere. ${ }^{33}$

No doubt Kauffmann intends a pun in his use of "camp" in the quotation above, since the homosexually-created style known as Camp was often associated with this approach to art. In her famous essay "Notes on Camp," published in the Partisan Review in 1964, Susan Sontag says: "Camp is the consistently aesthetic experience of the world. It incarnates a victory of 'style' over 'content,' 'aesthetics' over 'morality,' of irony over tragedy." ${ }^{34}$ As with Kauffmann's essay, gay readers have always been uneasy about Sontag's ostensibly sympathetic analysis. ${ }^{35}$ One reason for this may be that it subtly reinforces the prevailing belief that homosexuals lack a super-ego. Although she refers to Camp as "third among the great creative sensibilities," in fact the other two contain all that is truly great in art, either the 
"truth, beauty and seriousness" of high art or the "anguish, cruelty and derangement" of "the most important works of the $20^{\text {th }}$ century"; her putting the works she calls Camp on the same level as the greatest works of western civilization, most of which are intensely moral and humane, seems almost derisive, and makes one wonder how serious she is and how real her admiration for Camp. In fact she distances herself from this apparent admiration at the beginning of the essay; she is "strongly drawn to Camp, and almost as strongly offended by it," she says, and she responds with "deep sympathy modified by revulsion." ${ }^{36}$ In the end, the essay comes across as an intellectual tour-de-force whose provocative tone masks a subtle contempt for the homosexual artist.

Sontag relates Camp to Pop Art, which is however "more flat and more dry, more serious, more detached, ultimately nihilistic. ${ }^{{ }^{37}}$ At the height of its popularity in the mid 1960s, Pop Art was also clearly associated with homosexual artists (such as Andy Warhol and Robert Rauschenberg) and with nihilism. Time magazine lumped them together in 1966: "Homosexual ethics and esthetics are staging a vengeful derisive counterattack on what deviates call the 'straight' world. This is evident in pop which reduces all to the trivial, and in the camp movement, which pretends that the ugly and banal are fun.. ${ }^{38}$ In the same year, in The Village Voice, Vivian Gornick denounced Camp as a mockery of heterosexuals and a manifestation of homosexual self-hatred; she noted that "the most directly stunning result of camp's influence is, of course, the raucous Pop Art vogue ... which has probably set the course of American art back some hundred years or so." She refers to the "shallow, mean-spirited empty-vesseled 'style' of camp," and clearly allies it with a nihilistic attitude. In a lengthy denunciation she associates homosexual literature with "the claim that emptiness is substance ... a literature which has grown out of the homosexual temperament and which is frightening in its steely-eyed slickness, its language of surfaces, its heartlessness, its unbearable loathing of humanity and all its activities. ${ }^{\prime 39}$ The tone of this essay demonstrates the level of hysteria that the fear of homosexual influence had at this point generated among intellectuals.

Robert Brustein frequently refers to Albee's work as "Camp." He complains that "while the nihilism of Pop Art, for example, is relatively open, the theater continues to simulate values and feign commitments" and he refers to the "subterranean nihilism" of playwrights like Albee ${ }^{40} \mathrm{He}$ says that in A Delicate Balance Albee seems to be trying to invest the conventional drawing room comedy with metaphysical significance, as T. S. Eliot did in The Cocktail Party; "but where Eliot was usually impelled by a religious vision, Albee seems to be stimulated by mere artifice, and the result is emptiness, emptiness, emptiness." ${ }^{\prime 11}$ In a carefully thought-out essay in 1965, "The Two Revolutions," he describes two trends that will shape the theatre of the future, one racial, the other sexual. "The Negro protest play...is essentially realistic, hortatory, affirmative, political, while the Bohemian 'camp play'...is formally experimental, playful, exhibitionistic, 
pessimistic, personal (or sometimes, as in the case of The Zoo Story and Tiny Alice, even fake-metaphysical and pseudo-religious). ${ }^{42}$ In his criticism, as in the commentaries of many others of the period, Camp and Pop Art are seen as equally baleful manifestations of gay nihilism.

The hysteria about gay influence on American culture, and especially the theatre, reached its height in the mid 1960s. Even Brustein, the intellectual liberal, stooped to the level of popular anti-homosexual rhetoric in the above-mentioned essay:

The terrible cultural insecurity of American audiences, coupled with the increasing power of self-appointed tastemakers, has already emboldened the women's magazines and chic weeklies to impose a homosexual style on our culture. This style began in fashions, infiltrated advertising, and then took over the art world and "underground" movies; it will undoubtedly begin to dominate the theatre soon as well. ${ }^{43}$

His decision to omit this passage when he republished part of the essay in book form later in 1965 suggests that he had second thoughts about this view, or perhaps second thoughts about revealing it. ${ }^{44}$ The apocalyptic tone reappears in a 1967 review of an openly gay spoof, Gorilla Queen by Ronald Tavel, a work that seemed to confirm all his worst fears: "The more apocalyptic among us will probably view Gorilla Queen as one more crack in the disintegration of Western civilization, and they are probably right: In Tavel, one can certainly see the Rough Beast beginning his slouch." Brustein stops short of blaming homosexual artists for this disintegration; rather, the success of their work reflects the decline of American culture as a whole: "the humanism being murdered in Gorilla Queen was already dying in the forms from which Camp draws its inspiration-bad movies, television, and the comic strips-and the paradox of the evening is how frequently the parody begins to approach the reality." ${ }^{45}$ Nonetheless, for Brustein homosexual artists are clearly in the vanguard of the social disintegration he fears.

A similar theme finds striking expression in a key work, Leslie Fiedler's 1965 essay "The New Mutants." The new mutants are the new generation of male college students, who seem to be rejecting the super-ego altogether; indeed, according to Fieldler their rallying cry is "Let id prevail over ego, impulse over order." They reject "that bourgeois-Protestant version of Humanism, with its view of man as justified by rationality, work, duty, vocation, maturity, success" and "are prepared to advocate prolonging adolescence to the grave."'In particular, Fiedler is shocked by their willingness to embrace "that sum total of rejected psychic elements which the middle-class heirs of the Renaissance have identified with women":46 
the Beatle hair-do is part of a syndrome, of which high heels, jeans tight over the buttocks, etc., are other aspects, symptomatic of a larger retreat from masculine aggressiveness to female allure - in literature and the arts to the style called 'camp'.... that style, though the invention of homosexuals, is now the possession of basically heterosexual males as well, a strategy in their campaign to establish a new relationship not only with women but with their own masculinity." ${ }^{47}$

Fieldler is careful not to say that this "new irrationalism," this rejection of the masculine super-ego, is caused by homosexuals, but he makes it clear that homosexual writers have facilitated the change. He calls William Burroughs the "chief prophet of the post-male post-heroic world" and he says that because heterosexual writers have been slow to catch up, the young have "perforce permitted homosexuals to speak for them (Burroughs and Genet and Baldwin and Ginsberg and Albee and a score of others), even to invent the forms in which the future will have to speak." ${ }^{48}$ In all this Fiedler does not question the assumption that women are not heirs to Renaissance humanism and heroism but irrational beings focused on alluring men, and that homosexual men are already the kind of mutants that he says the youth of his day are becoming. The apocalyptic tone of the essay is clearly motivated by Fiedler's alarm at the challenges being presented by the young to the 1950s ideal of masculinity and male authority, and to the virtues of "maturity, intelligence [and] control" that Brustein and the psychiatrists of the period saw as the marks of normal heterosexual manhood.

As Michael Sherry notes, hysteria about the homosexual influence reached its pitch in 1966-67, and then abruptly dissipated. Commentators like Hayes, Brustein, Kauffmann, Fiedler, and others (though not Blau), having seemingly felt that homosexuals were bringing about - or at least paving the way for - the end of civilization, suddenly dropped the topic altogether. Sherry suggests a number of factors might have caused this abrupt shift, including the decline of culture as a weapon in the Cold War and the rise of the discourse of gay liberation. But as he notes: "Resurgent feminism was the key." ${ }^{\prime \prime 9}$ Betty Friedan's The Feminine Mystique (1963) touched off a remarkable and rapid shift in middle-class attitudes, indicated, for example, by the doubling of the divorce rate between the mid-1960s and the mid-1970s. ${ }^{50}$ Newly politicized gay men joined feminists in their attacks on the traditional masculine image, and the exposure of the pervasive misogyny of heterosexual men made the latter's attacks on the misogyny of homosexual playwrights suddenly seem hypocritical. An indication of the speed of this change and its consequences can be seen in Rosalyn Regelson's 1968 article in the Sunday 
New York Times, "Up the Camp Staircase," which already seems to belong to a new era. After scornfully surveying the critical homophobia of the last decadethe "brouhaha of a couple of years ago about secret homosexual charades by our leading dramatists," the view that successful plays by homosexual playwrights were "esoteric missiles in a guerrilla attack by the "Homosexual Underground," and "the prevailing idea that Pop-Camp equals trivial equals homosexual"proceeds to accuse both critics and homosexual playwrights of being out of date:

The Now Generation's rejection of the old norms has not yet extended to what might be called the Then Generation, which is still more or less in charge, but it puts many old attitudes on the road to obsolescence .... The fact is that we have not yet had a playwright, heterosexual or homosexual, who has been sufficiently liberated from our outmoded concepts of marriage and psychosexual identity to present the conflicts we are all experiencing - conflicts resulting from the gap between our mental image of what we should be and our gut feelings. We are hurtling toward the $21^{\text {st }}$ century and new social and personality configurations; a significant part of our psyches is already tuned in to the future but our theater looks backward, doing business as usual in the claustrophobic confines of the Suffering Family. ${ }^{51}$

Faced with a world of "new social and personality configurations," faced with the revolutionary demands of their wives and daughters, men in liberal circles simply could not maintain the masculine ideal to which they had previously been so committed. Heterosexual men were forced to think of themselves differently, and the image of the authoritative paterfamilias providing for his family and setting an example of rational and responsible behavior no longer seemed viable. As Ehrenreich notes in her survey of social behavior in the late 1960s and 1970s, most middle-class men seemed to adapt to the new image of their gender remarkably quickly. She describes various trends among men that reflected a diminished sense of responsibility and a new willingness to view themselves as in need of help rather than as having everything under control; these included men divorcing their wives for younger women or not marrying at all, men embracing the trappings of the hippy counter-culture, and men acknowledging their vulnerability by taking up such pursuits as encounter therapy or physical fitness. Ehrenreich is ambivalent about whether women were actually better off as a result of this feminist-inspired change in the male self-image. ${ }^{52}$

The speed with which the anti-homosexual panic dissipated is an indication of its irrational origins. While the Freudian theory of the super-ego, as interpreted by American psychiatrists, formed the intellectual underpinnings of the attacks 
on homosexual artists, its real origins lay in the pressure men felt to preserve a masculine self-image, which was defined to a considerable extent as "not being homosexual." As men began to feel increasing uncertainty about this self-image by the mid 1960s, their fears were projected even more strongly onto the gay artists who they believed were undermining it. When they were finally forced to abandon the traditional male ideal, the fears disappeared, and so did the apocalyptic predictions of homosexuality destroying civilization as we know it. ${ }^{53}$ It is true that Freud's influence also declined during this period, a decline in which feminism played a major role; feminists like Kate Millett unleashed a blistering attack on Freud from which he never recovered. ${ }^{54}$ But one suspects that the loss of faith in psychoanalysis was less an intellectual realization of the inadequacy of Freudian theory than another casualty of the shift in male self-image among intellectuals, who no longer felt the need to preserve the "masculine moral character" that Freud and Trilling believed was necessary to save civilization and no longer feared the accusation of "latent homosexuality" that had enforced their conformity to traditional patterns of male behavior. What is sobering in the end is the realization that some of the most intelligent and rational men of the period - men like Brustein and Fiedler - could allow their thought to be driven to such a large extent by unconscious emotion, by what was in fact prejudice in the broadest sense. Ironically, it was Freud more than anyone who made us aware that our most sophisticated conscious reasonings are often rationalizations of our most primitive desires and fears.

\section{Notes}

1. Joseph Hayes, "Distorted Views: Theatre Misrepresents America," The New York Times 11 August 1963: 2.1.

2. Howard Taubman, "Not What It Seems: Homosexual Motif Gets Heterosexual Guise," The New York Times 5 November 1961:2.1. For general discussions of homophobia among critics of this period, see John M. Clum, Still Acting Gay: Male Homosexuality in Modern Drama (New York: St Martin's Griffin, 2000) 142-47 and Kaier Curtin, “We Can Always Call Them Bulgarians”: The Emergence of Lesbians and Gay Men on the American Stage (Boston: Alyson, 1987) 320-31.

3. Hayes 2.1. For the view that this interpretation of Who's Afraid of Virginia Woolf" was a touch-stone of critical homophobia, see my article, "Homophobic Criticism and Its Disguises: The Case of Stanley Kauffmann,” The Journal of Dramatic Theory and Criticism 16.2 (Spring 2002): 95-110.

4. Michael S. Sherry, Gay Artists in Modern American Culture: An Imagined Conspiracy (Chapel Hill: U of North Carolina P, 2007).

5. See Kenneth Lewes, The Psychoanalytic Theory of Male Homosexuality (New York: New American Library, 1988) 35-43, 180-82, and 217-18.

6. Sigmund Freud, Civilization and Its Discontents, trans. James Strachey (New York: Norton, 1990) 83-84.

7. Lionel Trilling, “On the Teaching of Modern Literature," Beyond Culture: Essays on Literature and Learning (New York: Viking, 1965) 24. The article was originally published as "On the Modern Element in Modern Literature" in the Partisan Review, January-February 1961.

8. Lionel Trilling, The Liberal Imagination: Essays on Literature and Society (London: Mercury Books, 1950) 240-41. 
9. Donald M. Kaplan, "Homosexuality and American Theatre: A Psychoanalytic Comment," Tulane Drama Review 9.3 (1965) 31-33.

10. 36-37. Kaplan emphasizes the baleful effect of the homosexual perversion on the theatre: "Homosexuality — actually and ideologically — has always hovered about the theatre like a specter.... however, it is my belief that the current theatre materializes this specter" (28-29).

11. "The Homosexual in America," Time 21 January 1966: 41.

12. Wilfrid Sheed, "Heterosexual Backlash," Commonweal 82 (12 May 1965): 290 and "Back to the Zoo," Commonweal 82 (9 July 1965): 502.

13. See Sigmund Freud, "Some Psychical Consequences of the Anatomical Distinction Between the Sexes (1925)," On Sexuality: Three Essays on the Theory of Sexuality and Other Works, The Penguin Freud Library vol. 7 (London: Penguin, 1991) 342.

14. Barbara Ehrenreich, The Hearts of Men: American Dreams and the Flight from Commitment (New York: Anchor, 1983) 14-28.

15. Laura Mulvey, "Visual Pleasure and Narrative Cinema," Feminist Film Theory: A Reader, ed. Sue Thornham, (New York: New York U P, 1999) 63.

16. Bentley discusses his homosexuality and psychoanalysis (he calls Freud his "guru" at the time) in the "Afterword" to The Kleist Variations (Baton Rouge: Oracle Press, 1982) 220-21. Kaplan, for example, states that "the notion that a stiff erection settles all issues ever worth settling between people ... is, of course, the central prepossession of the homosexual" (Kaplan 44).

17. Eric Bentley, "Pity the Dumb Ox," The New Republic 16 March 1953: 22.

18. Herbert Gold, "The Beat Mystique: What It Is, Whence It Came," Playboy (February 1958): 85, 87. The essay is republished as "Hip, Cool, Beat and Frantic" in The Age of Happy Problems (New York: Dial, 1962) 79-90.

19. $85-86$.

20. The term "male impersonator" became a code word among some critics for overtly "masculine" characters created by homosexual playwrights. John Simon was still using it in 1971. See his review of Terrence McNally's Where Has Tommy Flowers Gone? ("Jesus Christ Supperclub Star," New York Magazine 25 October 1971: 83).

21. Robert Brustein, "America's New Culture Hero: Feelings Without Words," Commentary 25 (February 1958): 123, 128, 129.

22. Robert Brustein, "The Men-taming Women of William Inge," Harper's Magazine (November 1958) 51,54 .

23. 54 .

24. $56,57$.

25. Lewes 36 .

26. In fact, Sartre's view is different, in that he portrays the homosexual Genet as embracing all that is defined as evil, not simply as having a childish lack of moral sense. For the Freudian, homosexuals are amoral; for Sartre, they are perversely immoral. Under both views, homosexuals lack morality and civilized values and so could be seen as nihilistic. See Jean-Paul Sartre, Saint Genet: Actor and Martyr, trans. Bernard Frechtman (New York: George Braziller, 1963), especially 73-137.

27. Clum 145. He cites as examples of this view Stanley Kauffmann, "Homosexual Drama and Its Disguises," The New York Times 23 January 1966: 2.1; Philip Roth, "The Play that Dare Not Speak Its Name," The New York Review of Books 25 February 1965: 4; Richard Schechner, "Who's Afraid of Edward Albee," Tulane Drama Review 7.3 (1963) 7-10.

28. Robert Brustein, "The Brothel and the Western World," The New Republic, 28 March 1960: 21.

29. Herbert Blau, The Impossible Theater: A Manifesto (New York: Macmillan, 1964) 299.

30. Herbert Blau, "Disseminating Sodom," Salmagundi, no. 58-59 (Fall 1982-Winter 1983): 223-24.

31. $248-49$.

32. Kauffmann 2.1.

33. See Arrell, "Homophobic Criticism and Its Disguises: The Case of Stanley Kauffmann," cited above.

34. Susan Sontag, "Notes on 'Camp'," Against Interpretation (New York: Farrar, Straus and Giroux, 1966) 287.

35. For examples of this uneasiness, see Sherry 136-37 and most of the authors who address Sontag's essay in The Politics and Poetics of Camp, ed. Moe Meyer (London: Routledge 1994). 
36. Sontag $286-87,276$.

37. 292.

38. "The Homosexual in America" 40.

39. Vivian Gornick, "It's a Queer Hand Stoking the Campfire," The Village Voice 7 April 1966: 21.

40. Robert Brustein, "Three Plays and a Protest," The New Republic 23 January 1965: 33, 36.

41. Robert Brustein, "Albee Decorates an Old House," The New Republic 8 October 1966: 35.

42. Robert Brustein, "The Two Revolutions," The New Republic 27 March 1965: 27.

43. 27.

44. See Robert Brustein, Seasons of Discontent: Dramatic Opinions 1959-1965 (New York: Simon and Schuster, 1965) 311-12.

45. Robert Brustein, "Notes from the Underground," The New Republic 6 May 1967: 30.

46. Leslie Fiedler, "The New Mutants," The Collected Essays of Leslie Fiedler, vol. 2 (New York: Stein and Day, 1971) 384, 385, 390.

47. 394-95.

48. 392,395 .

49. Sherry 204, 211.

50. Ehrenreich 120.

51. Rosalyn Regelson, "Up the Camp Staircase," The New York Times 3 March 1968: D.15.

52. Ehrenreich 170.

53. In my article cited above, I argue that this pattern of the treatment of gay men reflects the process of "scapegoating" as described by social psychologists.

54. Kate Millett, Sexual Politics (1969; rpt. New York: Avon, 1971)176-203. 